
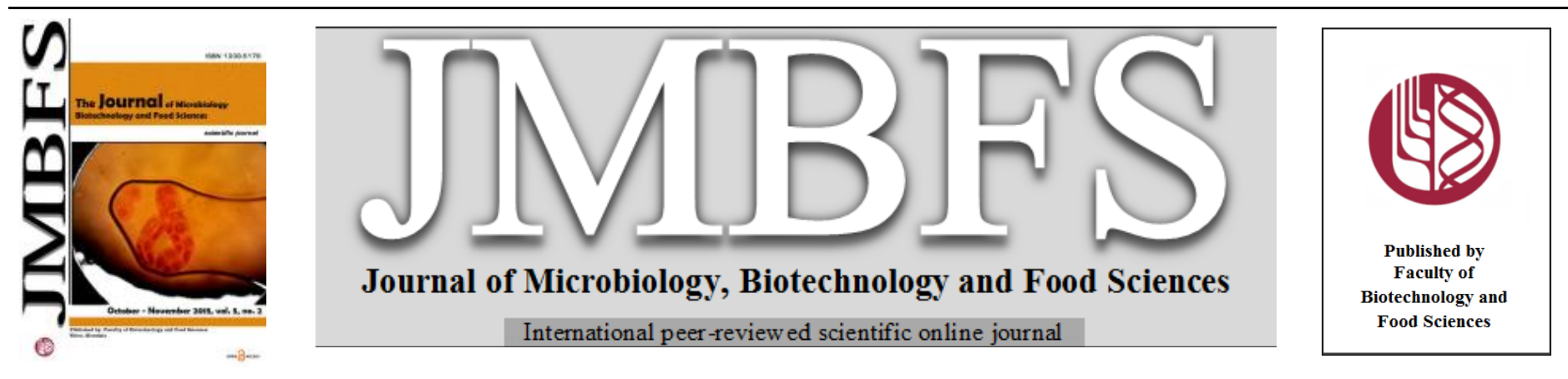

\title{
COAT PROTEIN GENE OF NEW ISOLATE OF CUCUMBER MOSAIC VIRUS INFECTING BANANA IN EGYPT
}

\author{
Abdelsabour G. A. Khaled ${ }^{1}$, Ahmed Wardany ${ }^{2}$ and Sabry Y. M. Mahmoud ${ }^{3,4}$ \\ Address(es): \\ ${ }^{1}$ Department of Genetics, Faculty of Agriculture, Sohag University, Sohag 82786, Egypt. \\ ${ }^{2}$ Department of Botany, Faculty of Science, El-Azher University, Assiut, Egypt. \\ ${ }^{3}$ Department of Microbiology, Faculty of Agriculture, Sohag University, Sohag 82786, Egypt. \\ ${ }^{4}$ Department of Medical Laboratory Technology, Faculty of Applied Medical Science, Hafr Al Batin Univ, Saudi Arabia.
}

*Corresponding author: younisabry@gmail.com

doi: 10.15414/jmbfs.2015.5.2.177-181

\section{ARTICLE INFO}

Received 21. 4. 2015

Revised 25. 5. 2015

Accepted 16. 7. 2015

Published 1. 10. 2015

$\underline{\text { Regular article }}$

open $\partial_{\text {ACCESS }}$

\begin{abstract}
Banana plants showing typical mosaic and yellow stripes on leaves as symptoms were collected from Assiut Governorate in Egypt. The causal agent was identified as Cucumber mosaic virus (CMV) on the basis of symptoms, transmission, serology, transmission electron microscopy (TEM) and reverse transcription polymerase chain reaction (RT-PCR). Coat protein (CP) gene was amplified using gene specific primer, followed by cloning into desired cloning vector and sequencing. In this study the CMV was transmitted into propagation host either by aphid or mechanically. The transmission was confirmed through direct antigen coating enzyme linked immunosorbent assay (DAC-ELISA). Analysis of the 120 deduced amino acid sequence of the coat protein gene revealed that the Eg-A strain of CMV shared from 97.50 to $98.33 \%$ with those strains belonging to subgroup IA. The cluster analysis grouped the Egyptian isolate with strains Fny and Ri8 belonging sub-group IA. It appears that there occurs a high incidence of CMV infecting banana belonging to IA subgroup in most parts of Egypt.
\end{abstract}

\section{INTRODUCTION}

Banana is considered the most important fruit in Egypt. Many clones are grown for the export market, but many indigenous cultivars are produced and consumed locally. Bananas are affected by five viruses (Diekmann and Putter 1996) these are Banana bunchy top virus (BBTV) genus Nanavirus, Banana streak virus (BSV) genus Badnavirus, Cucumber mosaic virus (CMV) genus Cucumovirus, Banana bract mosaic virus (BBrMV) genus Potyvirus, and Banana mild mosaic virus (BanMMV), (Thomas et al., 2000; Gambley and Thomas 2001). Banana mosaic has been shown to be widespread in banana and also been noted in bananas from Africa, the Americas, Southeast Asia, and Australia (Lockhart and Jones 2000; Thomas et al., 2000). The occurrence of CMV has been reported in many hosts such as Egyptian henbane (Samad et al., 2000), gladiolus (Raj et al., 2002), Tomato (Sudhakar et al., 2006), Geranium (Verma et al., 2006), banana (Aglave et al., 2007), Rauvolfia serpentina and Jatropha curcas (Raj et al., 2007). CMV is an icosahedral virus approximately $28-30 \mathrm{~nm}$ in diameter and belongs to the genus Cucumovirus in the family Bromoviridae. The virus is rapidly transmitted by more than 80 aphid species in a non-persistent manner (Palukaitis et al., 1992).

The genome of Cucumber Mosaic Virus (CMV) contains three, positive-sense, single-stranded RNAs packaged in separate particles (Peden and Symons 1973; Palukaitis $\boldsymbol{e t} \boldsymbol{a l}$. , 1992). RNA1 and RNA2 encodes for the protein 1a and 2a, respectively which forms the replicase complex (Palukaitis et al., 1992). Nterminal region of $1 \mathrm{a}$ protein contains putative methyltransferase domain (Rozanov et al., 1992) and C-terminal region shows sequence similarity to viral helicases (Gorbalenya et al., 1989). The CMV RNA3 encodes two proteins, 3a, a cell-to-cell movement protein (MP) (Ding et al., 1995) and 3b or the capsid protein $(\mathrm{CP})$; this latter protein being translated from a subgenomic RNA4 (Schwinghamer and Symons 1977). CP is involved in cell-to-cell movement, virion assembly and aphid-mediated transmission (Boccard and Baulcombe 1993; Perry et al., 1994). CMV has a very broad host range of wild and cultivated plants, with more than 1300 known hosts including some monocotyledons and a great number of dicotyledons (Chen et al., 2006). CMV isolates have been divided into two subgroups (named I and II) based on different methods such as: serological data, amino acids of the coat protein, nucleic acid hybridization and nucleotide sequence similarities. Roossinck et al. (1999) suggested further division of subgroup I strains into IA and IB, on the basis of the results of phylogenetic analyses. Previously, Daniels (1992) had proposed that CMV subgroup I be subdivided into Ia and Ib on the basis of host reaction and dsRNA patterns. Aim of our study illustrates detection and cloning of CP gene of CMV isolate to correctly identify the disease and to assess similarity or variability among isolates of CMV infecting banana in Egypt as well as other CMV isolates from rest of the world.

\section{MATERIAL AND METHODS}

The present investigations were undertaken to identify the causal virus based on biological, serological and molecular testing. The research work has been carried out at Botany Department, Faculty of Sciences, Al-Azhar University, Assiut and Genetic Department, Faculty of Agriculture, Sohag University, Sohag, Egypt.

\section{Plant samples}

Banana plants (Musa sp. Cv. Williams) showing leaf mosaic, yellow stripes, leaf distortion and stunting of plant were collected from some farms in Assiut, Egypt. Virus cultures were maintained under insect proof glass house condition.

\section{Viral isolation and mechanical transmission}

Naturally infected banana leaves were used for preparing inoculum with $0.1 \mathrm{M}$ phosphate buffer $\mathrm{pH}$ 7.0. Pure culture was maintained by obtaining single lesion from Chenopodium amaranticolor Coste \& Reyn and inoculating it on to Nicotiana glutinosa L. The virus was further multiplied on the hosts such as $N$. tabacum cv. White Burly and healthy cv. Williams banana virus-free plants These hosts were grown in an insect proof glass house. The inoculated plants were serologically tested using CMV antiserum. 


\section{Aphid transmission}

Individuals of the aphids Aphis gossypii collected from cotton plants and $A$ craccivora collected from cowpea. Insects of aphids Aphis gossypii and A. craccivora. New generation of aphids were transferred to other healthy plants of cotton and cowpea growing in insect proof cages and the aphids were left for reproduction. Several virus free adults of each of the above mentioned aphids were starved for two hours.

They were allowed to feed for 20 min (acquisition period) on N. tabacum plants After that the aphids were transferred to healthy Nicotiana glutinosa and Cucumis sativus allowed to feed for 10-15 min (inoculation period), and then the insects were sprayed by insecticide (Malathion). The plants were maintained in insect proof cage at $25-30^{\circ} \mathrm{C}$ for 30 days and the plants were inspected daily for symptoms development. The aphid inoculated plants were serologically tested using CMV antiserum.

\section{CMV detection by enzyme-linked immunosorbent assay (ELISA)}

Direct antigen coating-ELISA (DAC- ELISA) test was performed as described by Clark and Joseph (1984) to test the presence of CMV in collected or inoculated plants using CMV antiserum. One g. of each leaf sample collected and ground in liquid nitrogen then, one $\mathrm{ml}$ of $0.2 \mathrm{M}$ potassium phosphate buffer with $0.5 \%$ sodium sulphite and $1 \%$ polyvinyl pyrolidone (PVP) was added to each sample The sample squeezed gently with absorbent cotton and equal volume of chloroform was added and vortexed thoroughly. The homogenate was centrifuged at $5000 \mathrm{rpm}$ for $5 \mathrm{~min}$ and the supernatant was used for coating the ELISA plates.

Cucumber Mosaic Virus antiserum provided by Dr. Rehab Dawood, Agriculture Reaearch Center, Dokki, Giza, Egypt was used for serodiagnosis study. Plates were coated with $200 \mu \mathrm{l}$ of prepared antigen sample and incubated at $37^{\circ} \mathrm{C}$ for $1 \mathrm{hr}$ or over night at $4^{\circ} \mathrm{C}$. After incubation, the well's contents were discarded and washed with PBS-T buffer thrice (flooding with PBS-T for 3 min every time) The blocking solution was added $(200 \mu \mathrm{l} /$ well $)$ and incubated for $1 \mathrm{hr}$ at $37^{\circ} \mathrm{C}$ After washing the plate (thrice with PBS-T), $200 \mu$ l of diluted rabbit antiserum (1: 500) was added in the wells and incubated at $37^{\circ} \mathrm{C}$ for $1 \frac{1}{2} \mathrm{hrs}$. The plate was washed and $200 \mu \mathrm{l}$ of enzyme conjugate (anti- rabbit alkaline phosphate) was added and incubated at $37^{\circ} \mathrm{C}$ for $1 \frac{1 / 2}{\mathrm{hrs}}$. After incubation, the plates were washed with PBS-T. After final washing, $200 \mu \mathrm{l}$ of substrate (p-Nitro phenyl phosphate$0.6 \mathrm{mg} / \mathrm{ml}$ ) was added and allowed for color development at room temperature by avoiding exposure to light. Then the reaction was stopped by adding $3 \mathrm{M} \mathrm{NaOH}$ and the color intensity was read in ELISA reader at $405 \mathrm{~nm}$.

\section{Electron microscopic study}

Banana leaves showing mosaic and yellow stripes resulted from mechanical transmission were collected for transmission electron microscopic studies. Samples were fixed in modified karnovsky fluid's (David $\boldsymbol{e t}$ al., 1973) buffered with 0.1 M Sodium Phosphate Buffer (pH 7.4). Fixation was done for $2 \mathrm{hrs}$ in $1 \%$ Osmium tetraoxide in the same buffer at $40^{\circ} \mathrm{C}$. After several washes in $0.1 \mathrm{M}$ Sodium Phosphate Buffer, the specimens were dehydrated in graded acetone solution and embedded in CY212 araldite. Ultra thin section of 60-80 nm thickness were cut using an ultra cut ultramicrotome and the sections were stained in alcoholic uracil acetate $(10 \mathrm{~min})$ and lead citrate $(10 \mathrm{~min})$, before examining corresponding grids under transmission electron microscope operated at $60-80 \mathrm{Kv}$

\section{RNA extraction and RT-PCR of coat protein $(\mathrm{CP})$ gene}

Approximately $100 \mathrm{mg}$ infected dry leaves of banana was frozen in liquid nitrogen and ground to powder with a mortar and pestle. Total RNA was extracted with $1 \mathrm{ml}$ TRIzol reagent, according to the instructions of the supplier using the method of Girin et al. (2007). After ethanol precipitation, the RNA was resuspended in $30 \mu \mathrm{l}$ RNase free water and treated with RNase free DNase (Ambion), which was then inactivated according to the instructions of the supplier. Approximately $5 \mu \mathrm{g}$ of total RNA were reverse transcribed using random hexamers (invitrogen) and Revertaid reverse transcriptase withou $\mathrm{RNaseH}$ activity (Fermentas) in a final volume of $20 \mu \mathrm{l}$. For RT-PCR, template was provided as $2 \mu \mathrm{l}$ of a 50 -fold dilution of cDNA in water in a total reaction volume of $20 \mu \mathrm{l}$. The CMV specific primers 5'-GCC GTA AGC TGG ATG GAC AA-3' and 5'-TAT GAT AAG AAG CTT GTT TCG CG-3' designed by Wylie $\boldsymbol{e} t$ al. (1993) were used for amplification a part of the CP gene and part of the $3^{\prime}$ noncoding region of CMV RNA3 and were designed to produce amplicons of different sizes to distinguish CMV isolates belonging to subgroups I or II (Singh et al., 1995). Amplification was done using Phusion DNA polymerase (Promega), with initial denaturation at $98^{\circ} \mathrm{C}$ for 2 min followed by 35 thermal cycles of $98^{\circ} \mathrm{C}$ for $15 \mathrm{~s}, 60^{\circ} \mathrm{C}$ for $30 \mathrm{~s}$, and $72^{\circ} \mathrm{C}$ for $30 \mathrm{~s}$ and followed by final extension at $72^{\circ} \mathrm{C}$ for $10 \mathrm{~min}$.

\section{Cloning and sequencing of $\mathrm{CP}$ gene}

A cDNA fragment of about 487 bp was cloned into pCR-Blunt-II-TOPO cloning vector (3519 bp, invitrogen), according to the instructions of the supplier. Colony PCR from selected clones were carried out using the same specific primers of RT-PCR for the conformation of insertion product of CP gene. The DNA sequencing of 3 independent positive clones was carried out using the Sanger method with fluorescent chain-terminating inhibitors di-deoxynucleotide (Smith et al., 1986). The BigDye ${ }^{\circledR}$ Terminator v3.1 Cycle Sequencing Kit (Life Technologies) was used to sequence plasmid DNA with the universal primers M13 forward and reverse on a Applied Biosystems 3100 System according to the indications of the supplier.

\section{Sequences analysis}

The partial coat protein (CP) gene sequence of Egypt isolate was submitted to National Center of Biotechnology Institute (NCBI) Database (KP324751) Multiple alignments of amino acid sequences and phylogenetic tree were obtained using the default options of the Clustal W program version 2.0 (Larkin et al., 2007). Search homologies with proteins from the BLAST basic local alignment search tool of NCBI was done with the FASTA (Pearson and Lipman 1988), and TBLASTN program 2.2.22+ (Altschul et al., 1990). The partia sequence of amino acids corresponding to $363 \mathrm{bp}$ fragment of coding sequences (CDS) of CP gene was compard with some other corresponding known CMV isolates as following: Tfn (Y16926), SD (AB008777), C7-2 (D42079), IA (AB042294), Ix (U20219), Nt9 (D28780), Fny (D10538), Ri8(AM183119), Y (D12499), Leg (D16405), LS (AF127976), Q (M21464) and Trk7 (L15336).

\section{RESULTS AND DISCUSSION}

\section{Transmission and serological diagnosis}

Twenty five plants of Chenopodium amaranticolor, Nicotiana. tabacum, $N$ glutinosa, Cucumis sativus and Banana were sap inoculated by using naturally infected banana extract (Figure 1A) and carborundum powder. The results revealed that tobacco plants expressed the CMV symptom after 22 days, while banana plants after 48 days of inoculation. Transmission of CMV causes severe mosaic and leaf deformations in inoculated plants, which was confirmed through DAC-ELISA. On another hand, $C$. amaranticolor expressed local lesion symptoms. Vector transmission studies using two aphid species A. craccivora and $A$. gossypii, both species are efficiently transmitted the virus in a nonpersistent manner within 20 min of acquisition and inoculation of 10 to $15 \mathrm{~min}$ Forty eight plants of Banana and Tobacco were inoculated with infective $A$. gossypii and A. craccivora. Inoculated plants showed the symptoms of CMV after 13-22 days of inoculation. These results revealed that the CMV is aphid transmissible and agreed with the data recorded by Rao (1980) who reported Successful transmission of CMV to test plants by A. Gossypii in this respect, Mali and Rajegore (1980) who indicated that CMV isolated from banana was transmitted by A. craccivora to healthy plants. His method is very efficient even in detecting symptom less plants. The results revealed that positive control recorded a mean absorbance of 0.382 . The negative control recorded a mean absorbance of 0.103 . The present investigation results has clearly revealed the occurrence and association of cucumber mosaic virus with banana chlorosis was identified based on mechanical transmission, insect vector transmission, hos range, serology DAC-ELISA detection. The virus was able to transmit mechanically on the plants used in the study very efficiently and produced the systemic and local symptoms characteristic of CMV. In our present study both the aphid species (A. gossypii and A. craccivora) transmitted the virus in non persistent manner. Serology is the most reliable and quick method of detection of CMV infection in banana (Rajasulochana et al., 2008). Dheepa and Paranjothi (2010) reported that CMV from banana could be transmitted mechanically and by aphid inoculation. CMV has the broadest host range among the plant viruses (Roosinck 2002) and has been reported infecting banana and causes banana chlorosis disease. 

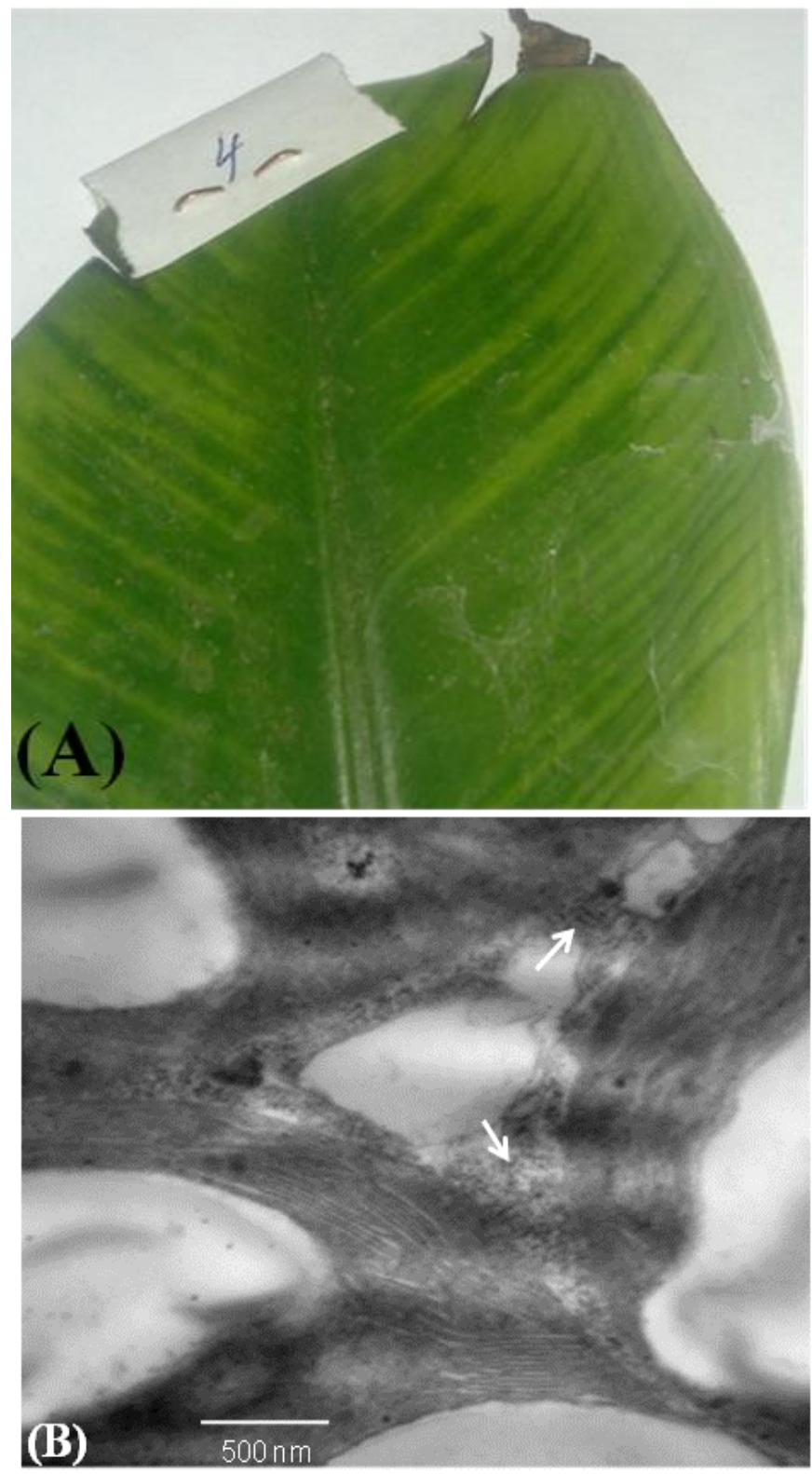

Figure 1 Cucumber Mosaic Virus (CMV) infected banana showed mosaic and yellow stripes in leaves (A) as naturally symptoms and Electron micrograph of a thin section of infected leaf sample of banana showing aggregates viral particle (B) (see arrows).

\section{Electron microscope studies}

Transmission electron microscopy of infected banana leaves revealed presence of a polyhedral virus particle of $\sim 28-29 \mathrm{~nm}$ diameters (Figure 1B). The shape and size of the virus particle were identical with those of CMV particle obtained from other sources.

\section{RT-PCR and cloning of coat protein gene}

PCR amplification of the CP gene using gene specific primers resulted in the amplification of $487 \mathrm{bp}$ fragment (Figure 2). After purification, PCR products were successfully cloned into pCRR-Blunt-II-TOPOR cloning vector. RT-PCR based detection systems significantly improves monitoring and forecasting of banana mosaic epidemics. Data presented in this study clearly indicate that $\mathrm{CP}$ region is sufficient to provide a simple and reliable method for detection and strain identification of banana CMV, in agreement with Khan et al. (2011).
Table 1 Comparisons of nucleotide sequence identities of deduced amino acids between Cucumber mosaic virus isolate (EG-A) and other CMV strains

\begin{tabular}{|c|c|c|}
\hline Strain & Sub-group & $\begin{array}{l}\text { Amino acid } \\
\text { Identity (\%) }\end{array}$ \\
\hline Tfn & \multirow{6}{*}{ IB } & 97.50 \\
\hline C7-2 & & 96.67 \\
\hline SD & & 97.50 \\
\hline IA & & 97.50 \\
\hline $\mathrm{Ix}$ & & 95.83 \\
\hline $\mathrm{Nt} 9$ & & 96.67 \\
\hline Fny & \multirow{4}{*}{ IA } & 98.33 \\
\hline Ri-8 & & 98.33 \\
\hline $\mathrm{Y}$ & & 96.67 \\
\hline Leg & & 97.50 \\
\hline LS & \multirow{3}{*}{ II } & 87.50 \\
\hline $\mathrm{Q}$ & & 87.50 \\
\hline Trk7 & & 85.00 \\
\hline
\end{tabular}

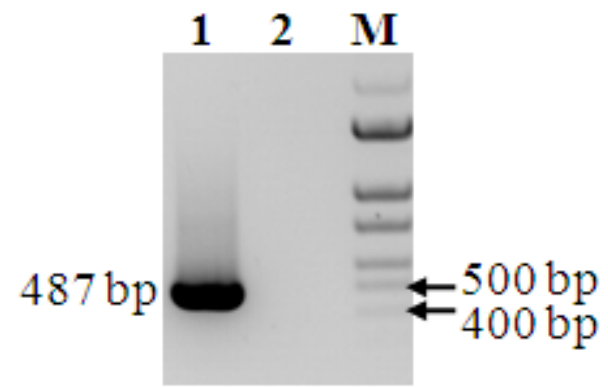

Figure 2 Gel photograph of RT-PCR amplicons: Lane 1, Amplified CMV CPEg-A sample, lane 2, negative control and M, 100 bp ladder.

\section{Sequences analysis}

Analysis of the 120 deduced amino acid sequence of the coat protein gene revealed that the Eg-A strain of CMV had 95.83 to $98.33 \%$ homology with subgroups IA and IB strains in this region (Table 1 and Figure 3). The Egyptian isolate shared from 97.50 to $98.33 \%$ with those strains belonging to subgroup IA, and from 95.83 to $97.50 \%$ with those belonging to subgroup IB. While the Eg-A isolate revealed low level of similarity $(85.00-87.50 \%)$ with those belonging to sub-group II. These results confirmed the placement of Eg-A isolate in subgroup I. The cluster analysis grouped the Egyptian isolate with strains Fny and Ri8 belonging sub-group IA. Palukaitis and Zaitlin (1997), and Roossinck (2002) documented that CMV subgroup I is further divided into IA and IB on the basis of sequences and phylogenetic relationships. Strains IA and II of this virus are distributed worldwide, whereas the strains of IB subgroup are mainly restricted to Asia (Roossinck 2002; Koundal et al., 2010).

The multiple sequence alignment (Figure 3) showed that the Egyptian isolate differs from all isolates used for comparison in the residue 39 and 58 of the $\mathrm{CP}$ which exhibits Serine (S) and Threonine (T), respectively, whereas all other isolates have Alanine (A) at these sites. Two strains (Fny and Ri8) of the four subgroup IA, had $98.33 \%$ identity with the Eg-A strain in the 120 amino acids of the coat protein gene and differs with them in these two residues only. In this direction, three out of the six subgroup IB strains used for comparison had three amino acid substitutions at various points $(1,39$ and 58) and had $97.5 \%$ amino acid identity with the Eg-A strain (Table 1 and Figure 3). It has been reported that substitution of this last amino acid affects symptom expression, inducing chlorosis instead of necrosis in infected tobacco plants (Mochizuki and Ohki, 2011). All the three strains belonging subgroup II used for comparison had $85 \%$ and $87.5 \%$ amino acid homology with the Eg-A strain and formed separately a distinct clade (Table 1 and Figure 4).

The variation in the phylogenetic trees obtained from the nucleotide and amino acid sequences is of course due to the redundancy of the genetic code but may also be due to the fact that only the $3^{\prime}$ coat protein coding region was translated and analyzed whereas both the 3 ' coat protein coding region and the $\mathrm{C}$ terminal noncoding nucleotide sequences were analyzed. Although the previous grouping of CMV strains into subgroups IA, IB and II was based on the phylogeny estimations with full $\mathrm{CP}$ open reading frame and rearrangements in the 5 ' nontranslated region of RNA 3 (Roossinck et al., 1999). In this study the partial 3 coat protein coding region sequences analyzed and also sufficiently for divided CMV strains into subgroups, these results in agreement with those obtained by Eni et al. (2008). 


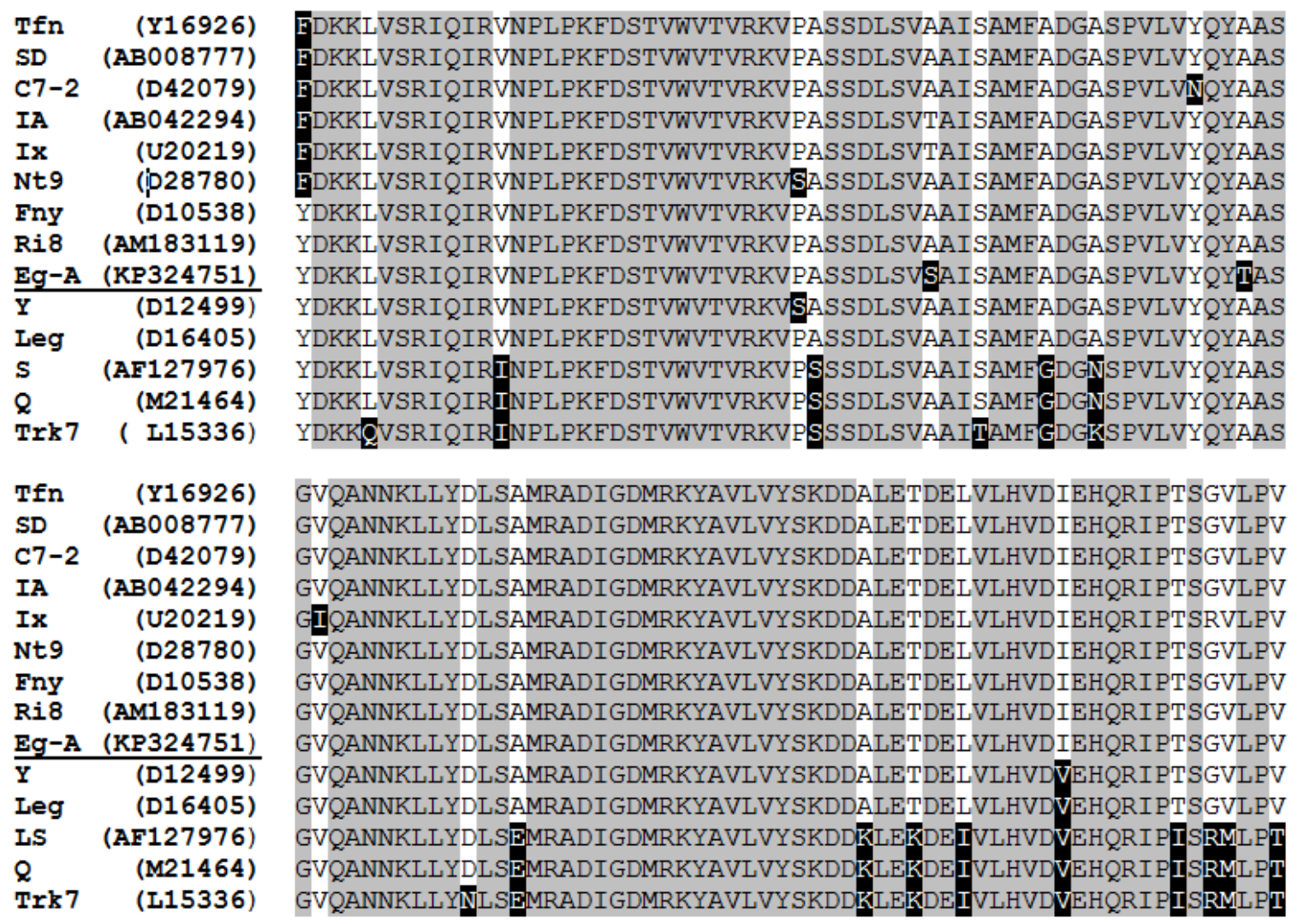

Figure 3 Alignment of amino acid sequences of Eg-A with some other CMV using 120 amino acid of CP gene. Regions with identical sequences highlighted in gray, regions with conserved sequences in the majority of the amino acid sequences are not highlighted and the regions with conserved sequences in one or some of the amino acid sequences are highlighted in black.

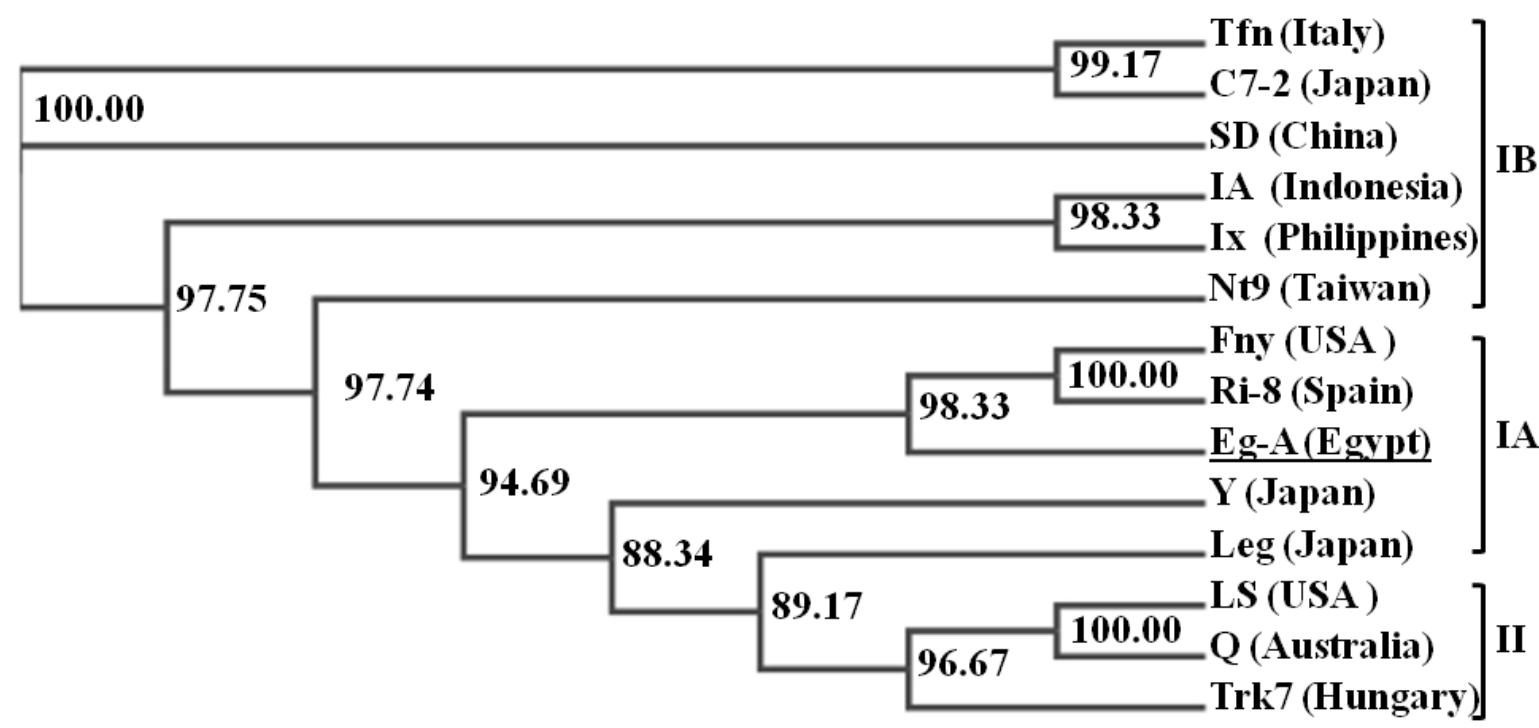

Figure 4 Phylogenetic tree drawn by Neighborhood Joining Bootstrap method based on the partial coat protein ORF sequences of 14 selected CMV isolates of subgroups IA, IB and II.

\section{CONCLUSION}

Cucumber mosaic disease caused by CMV has attained a serious status in most of the banana growing areas. Importance of the disease stems from the fact that it is responsible for losses to $40 \%$. Aim of our study illustrates detection and cloning of $\mathrm{CP}$ gene of $\mathrm{CMV}$ isolate to correctly identify the disease and to assess similarity or variability among isolates of CMV infecting banana in Egypt as well as other CMV isolates from rest of the world. For this, coat protein gene of CMV isolate collected from Assiut Governorate was cloned and sequenced. High degree of nucleotide sequence identity (97-98\%) between isolates belonging to subgroup IA. These resuls were confirmed by electron microscopy and transmission. Transmission was confirmed through DAC-ELISA technique. It has been concluded that the transmission of CMV was more successful to $N$. tabacum and $N$. glutinosa by mechanically and through aphids.

\section{REFERENCES}

AGLAVE B.A., KRISHNAREDDY M.P., ANDHALE M.S. 2007. Molecular identification of a virus causing banana chlorosis disease from Marathwada region. International Journal of Biotechnology \& Biochemistry, 3, 13-23. ALTSCHUL S.F., GISH W., MILLER W., MYERS E.W., LIPMAN D.J. 1990 Basic local alignment search tool. Journal of Molecular Biology, 215 (3), 403410. http://dx.doi.org/10.1016/s0022-2836(05)80360-2

BOCCARD F., BAULCOMBE D. 1993. Mutational analysis of cis-acting sequences and gene function in RNA3 of cucumber mosaic virus. Virology. 193(2), 563-578. http://dx.doi.org/10.1006/viro.1993.1165.

CHEN C. C., HSU H. T., CHIANG F. L., CHANGL C. A. 2006. Serological and Molecular Properties of Five Potyviruses Infecting Calla Lily. Proc. XIth IS on Virus Diseases in Ornamentals. Acta Hort. 722, 259-264. 
CLARK M.F., JOSEPH B. 1984. Enzyme Immuno Sorbent Assay in Plan Virology In: Methods in Virology, K. Maramorsch and Koprowski (Eds.), Academic Press, New York 7, 51-85. http://dx.doi.org/10.1016/b978-0-12 470207-3.50009-7.

DANIELS J. 1992. Characterization of Cucumber mosaic virus isolates from California. Plant Diseases, 76, 1245. http://dx.doi.org/10.1094/pd-76-1245

DAVID G.F.X., HERBERT J. \&. WRIGHT C.D.S. 1973. Ultrastructure of the pineal ganglion in the ferret. Journal of Anatomy, 115, 79:97.

DHEEPA R., PARANJOTHI S. 2010. Transmission of Cucumber Mosaic Virus (CMV) infecting banana by aphid and mechanical methods. Emirates Journal of Food and Agriculture, 22, 117-129.

DIEKMANN, D. R., C. A. J. PUTTER. 1996. Musa, 2nd. FAO/I/PGR Technical Guidelines for the Safe Movement of Germplasm, No.15, FAO Rome IIPGRI Rome, 28 pp.

DING S.W., LI W.X. \& SYMONS R.H. 1995. A novel naturally occurring hybrid gene encoded by a plant RNA virus facilitates long distance virus movement. The EMBO Journal, 14, 5762-577.

ENI A.O., KUMAR P.L., ASIEDU R., ALABI O.J., NAIDU R.A., HUGHES J.A., REY M.E.C. 2008. First Report of Cucumber mosaic virus in Yams Dioscorea spp.) in Ghana, Togo, and Republic of Benin in West Africa. Plant Disease, 92(5), 833-833. http://dx.doi.org/10.1094/pdis-92-5-0833b.

GAMBLEY C. F., THOMAS J. E. 2001. Molecular characterization of banana mild mosaic virus: a new filamentous virus in Musa spp. Arch. Virology, 146(7), 1369-1379. http://dx.doi.org/10.1007/s007050170097.

GORBALENYA A.E., KOONIN E.V., DONCHENKO A.P., BLINOV V.M. 1989. Two related superfamilies of putative helicases involved in replication, recombination, repair and expression of DNA and RNA genomes. Nucleic Acids Research, 17(12), 4713-4730. http://dx.doi.org/10.1093/nar/17.12.4713

GIRIN T., LEJAY L., WIRTH J., WIDIEZ T., PALENCHAR P.M., NAZOA F., TOURAINE B., GOJON A., LEPETIT M. 2007. Identification of a 150 bp cisacting element of the AtNRT2.1 promoter involved in the regulation of gene expression by the $\mathrm{N}$ and $\mathrm{C}$ status of the plant. Plant Cell Environment, 30(11), 1366-1380. http://dx.doi.org/10.1111/j.1365-3040.2007.01712.x

KHAN S., JAN A.T., AQUIL B., MOHD Q., HAQ R. 2011. Coat protein gene based on characterization of cucumber mosaic virus isolates infecting banana in India. Journal of Phytology, 3, 94-101

KOUNDAL V., HAQ Q., PRAVEEN S. 2010. Characterization, Genetic Diversity, and Evolutionary Link of Cucumber mosaic virus Strain New Delhi from India. Biochemical Genetics, 49(1-2), 25-38 http://dx.doi.org/10.1007/s10528-010-9382-8.

LARKIN M.A., BLACKSHIELDS G., BROWN N.P., CHENNA R., MCGETTIGAN P.A., MCWILLIAM H., VALENTIN F., WALLACE I. M., WILM A., LOPEZ R., THOMPSON J. D., GIBSON T. J., HIGGINS D. G. 2007. Clustal W and Clustal X version 2.0. Bioinformatics, 23(21), 2947-2948. http://dx.doi.org/10.1093/bioinformatics/btm404

LOCKHART B.E.L., JONES D.R. 2000. Banana mosaic. In: Diseases of Banana Abaca and Enset (Jones, D.R. Ed.), CABI publishing, UK, 256-263 pp.

MALI V.R, RAJEGORE S.B. 1980. A cucumber mosaic virus disease of banana in India. Phytopathology, 98(2), 127-136. http://dx.doi.org/10.1111/j.14390434.1980.tb03725.x

MOCHIZUKI T., OHKI S.T. 2011. Single amino acid substitutions at residue 129 in the coat protein of Cucumber mosaic virus affect symptom expression and thylakoid structure. Archives of Virology, 156(5), 881-886. http://dx.doi.org/10.1007/s00705-010-0910-y

PEARSON W.R., LIPMAN D.J. 1988. Improved tools for biological sequence comparison. Proceedings of the National Academy of Sciences USA. 85, 2444 2448.

PALUKAITIS P., ROOSSINCK M.J., DIETZGEN R.G., FRANCKI R.I.B. 1992 Cucumber mosaic virus. Advances in Virus Research, 41, 281-348. http://dx.doi.org/10.1016/s0065-3527(08)60039-1

PALUKAITIS P., ZAITLIN M., 1997. Replicase-mediated resistance to plant virus disease. Advances in Virus Research 48: 349-377.

PEDEN K.W.C., SYMONS R.H. 1973. Cucumber mosaic virus contains a functionally divided genome. Virology, 53(2), 487-492. http://dx.doi.org/10.1016/0042-6822(73)90232-8

PERRY K.L., ZHANG L., SHINTAKU M.H., PALUKAITIS P. 1994. Mapping determinants in cucumber mosaic virus for transmission by Aphis gossypii. Virology, 205(2), 591-595. http://dx.doi.org/10.1006/viro.1994.1686

RAJ S.K., SRIVASTAVA A., CHANDRA G., SINGH B.P. 2002 Characterisation of Cucumber mosaic virus isolate infecting Gladiolus cultivars and comparative analysis of serological and molecular methods for sensitive diagnosis. Current Science, 83, 1132-1136.

RAJASULOCHANA P., DHAMOTHARAN R, SRINIVASULU P. 2008 . Comparison of DAC-ELISA and DOT-BLOT-ELISA for the detection of cucumber mosaic and banana streak viruses infecting banana. The Journal of American Science, 4, 18-27.

RAO D.G. 1980. Studies on a new strain of banana mosaic virus in South India. In: Proc. National Seminar on Banana Production Technology. Muthukrishnan C.R. \& Abdul Khader J.B.M. (Eds.). Tamilnadu Agriculturual University, Coimbatore, India, 155-159 pp.
ROOSSINCK M.J., ZHANG L. HELLWALD K.H. 1999. Rearrangements in the 5 ' nontranslated region and phylogenetic analyses of Cucumber mosaic virus RNA 3 indicate radial evolution of three subgroups. Journal of Virology, 73 , 6752-6758.

ROOSSINCK M.J. 2002. Evolutionary history of cucumber mosaic virus deduced by phylogenetic analyses. Journal of Virology, 76(7), 3382-3387. http://dx.doi.org/10.1128/jvi.76.7.3382-3387.2002

ROZANOV M.N., KOONIN E.V., GORBALENYA A.E. 1992. Conservation of the putative methyltransferase domain: a hallmark of the 'Sindbislike' supergroup of positive-strand RNA viruses. Journal of General Virology, 73(8), 2129-2134. http://dx.doi.org/10.1099/0022-1317-73-8-2129

SAMAD, A., RAJ S. K., SRIVASTAVA A., CHANDRA G., AJAYAKUMAR

P. V., ZAIM M., SINGH B.P. 2000. Characterization of a cucumber mosaic virus isolates infecting Egyptian henbane (Hyoscyamus muticus L.) in India. Acto Virologica, 44, 131-136.

SCHWINGHAMER M.W., SYMONS R.H. 1977. Translation of the four major RNA species of cucumber mosaic virus in plant and animal cell-free systems and in toad oocytes. Virology, 79(1), 88-108. http://dx.doi.org/10.1016/0042 6822(77)90337-3

SINGH Z., JONES R.A.C., JONES M.G.K. 1995. Identification of cucumber mosaic virus subgroup I isolates from banana plants affected by infectious chlorosis disease using RT-PCR. Plant Diseases, 79(7), 713. http://dx.doi.org/10.1094/pd-79-0713

SMITH L.M., SANDERS J.Z., KAISER R.J., HUGHES P., DODD S., CONNELL C.R., HEINER C., KENT S.B.H. \& HOOD L.E. 1986. Fluorescence detection in automated DNA sequence analysis. Nature. 321(6071), 674-679. http://dx.doi.org/10.1038/321674a0

SUDHAKAR N., NAGENDRA-PRASAD D., MOHAN N., MURUGESAN K. 2006. First report of Cucumber mosaic virus subgroup II infecting Lycopersicon esculentum in India. Plant Diseases, 90(11), 1457. http://dx.doi.org/10.1094/pd90-1457b

THOMAS J.E., LOCKHART B.E.L., ISKRA-CARUANA M. L. 2000. Banan mild mosaic virus. In: Diseases of banana, Abaca and Ensete, D. R. Jones (Ed.). CAB International, Wallingford, UK, 275-279 pp.

VERMA N., MAHINGHARA B.K., RAM R., ZAIDI A.A. 2006. Coat protein sequence shows that Cucumber mosaic virus isolate from geraniums (Pelargonium Sp.) belongs to subgroup II. Journal of Biosciences, 31(1), 47-54 http://dx.doi.org/10.1007/bf02705234

WYLIE S., WILSON C.R., JONES R.A.C., JONES M.G.K. 1993. A polymerase chain reaction assay for Cucumber mosaic virus in lupin seeds. Australian Journal of Agricultural Research, 44(1), 41. http://dx.doi.org/10.1071/ar9930041 